\title{
Manajemen Risiko Sistem Informasi pada Perpustakaan Daerah Purwokerto
}

\author{
Ranggi Praharaningtays Aji ${ }^{1}$, Maruf Maftukhin ${ }^{2}$, Rizky Bangkit Bachtiar ${ }^{3}$ \\ 1,2,3 Universitas Amikom Purwokerto ; Jl Letjen Pol Soemarto Watumas Purwanegara, \\ Purwokerto Utara, Banyumas, 53123, Telp. (0281) 623321. \\ ${ }^{1,2,3}$ Program Studi Sistem Informasi, Fakultas Ilmu Komputer, Universitas Amikom Purwokerto \\ ${ }^{1}$ ranggi.p.aji@amikompurwokerto.ac.id
}

\begin{abstract}
Abstrak
Dinas Arsip dan Perpustakaan Daerah Kabupaten Banyumas sebagai penyedia pengarsipan dan perpustakaan di Banyumas dituntut untuk memberikan layanan informasi yang cepat, tepat, dan akurat. Guna memenuhi tuntutan tersebut maka Perpustakaan Daerah Purwokerto telah menerapkan sistem informasi dalam operasional sehari-harinya. Dengan penggunaan sistem informasi tersebut maka menimbulkan ancaman yang jika tidak diketahui secara tepat dapat menimbulkan kerugian bagi Perpustakaan Daerah Purwokerto. Tujuan dari penelitian ini adalah melakukan penilaian risiko pada sistem informasi yang ada di Perpustakaan Daerah Purwokerto. Untuk itu digunakan NIST SP 800-30 Rev1 yang merupakan model penilaian risiko yang dikeluarkan oleh National Institute of Standards and Technology. Hasil dari penelitian ini berupa penilaian atas 13 ancaman yang teridentifikasi terdapat pada Perpustakaan Daerah Purwokerto. Dimana 1 diantara 13 ancaman tersebut merupakan ancaman bertingkat tinggi dan terdapat 2 ancaman yang memiliki tingkatan rendah namun berdampak sangat besar jika sampai terjadi. Rekomendasi yang dihasilkan dari penelitian ini adalah Perpustakaan Daerah Purwokerto perlu membuat aturan tertulis untuk menangani risiko dari 13 ancaman yang diteliti dan menempatkan petugas keamanan di lokasi terdapatnya aset sistem informasi.
\end{abstract}

Kata kunci: Risiko, NIST SP 800-30 Rev1, Manajemen Risiko

\begin{abstract}
The Regional Archives and Libraries Office of Banyumas Regency as a provider of archives and libraries is often demanded to provide fast, precise, and accurate information services. In order to fulfill this case, the Purwokerto Regional Library has implemented an information system on a daily basis. With the use of this information system, it will pose a threat and if it is not known precisely, it can cause harm to the Purwokerto Regional Library. The purpose of this research is to measure the risk in the information system in the Purwokerto Regional Library. For this reason, NIST SP 800-30 Rev1 is used, which is a risk assessment model issued by the National Institute of Standards and Technology. The results of this study were in the form of an assessment of the 13 identified threats found in the Purwokerto regional library. The recommendation of this research is that the Purwokerto Regional Library needs to make written rules to handle the risks of the 13 threats studied, and place security officers in locations where information system assets are present.
\end{abstract}

Keywords: Risk, NIST SP 800-30 Rev1, Risk Management 


\section{PENDAHULUAN}

inas Arsip dan Perpustakaan Daerah Kabupaten Banyumas atau yang lebih dikenal

ก dengan Perpustakaan Daerah Purwokerto merupakan dinas yang bertugas memberikan pelayanan kearsipan dan perpustakaan di daerah Kabupaten Banyumas. Untuk memberikan layanan yang maksimal Perpustakaan Daerah Purwokerto telah menggunakan teknologi informasi dalam kegiatan operasionalnya. Beberapa contoh teknologi yang digunakan antara lain penggunaan sistem informasi perpustakaan, perpustakaan online, dan disediakannya layanan komputer umum pada gedung Perpustakaan Daerah Purwokerto.

Dengan penggunan teknologi informasi memunculkan juga risiko yang jika tidak ditangani secara benar dapat merugikan [1]. Beberapa contoh permasalahan yang sudah muncul saat ini adalah berhentinya operasi perpustakaan daerah jika listrik dari PLN padam [2], terdapat beberapa komputer yang terkena virus akibat flashdisk pengunjung perpustakaan [2], dan masih banyak lagi masalah yang muncul. Untuk itu perlu dilakukan manajemen risiko untuk dapat mengetahui ancaman apa saja yang dapat menimbulkan bahaya kepada Perpustakaan Daerah Purwokerto.

Penerapan model yang digunakan untuk melakukan proses evaluasi yaitu NIST SP 80030 Rev1. NIST SP 800-30 Rev1 merupakan model panduan yang dikeluarkan oleh National Institute of Standards and Technology untuk melakukan penilaian risiko pada sebuah instansi atau organisasi [3]. Penilaian risiko pada NIST SP 800-30 Rev1 dilakukan dengan cara melakukan identifikasi aset, pencarian sumber ancaman dan peristiwa ancaman, mengukur keseringan ancaman terjadi, menilai dampak dan terakhir menilai risiko dari ancaman yang ada [4].

Beberapa penelitian terdahulu telah menerapkan model penilaian risiko ini untuk melakukan penilaian risiko diobjeknya masing-masing. Seperti yang dilakukan oleh Dini, dkk dengan melakukan identifikasi risiko pada Perpusda Gresik [2]. Berikutnya ada Bavian, dkk yang melakukan manajemen risiko pada Dinas Kominfo Provinsi Jawa Timur yang menghasilkan dokumen manajemen risiko [5]. Dan ada pula penelitian yang dilakukan oleh Ruszullah, dkk [6] pada E-learning Universitas Narotama, serta Obrina, dkk [7] pada PT-ABC, serta terdapat juga penelitian dari Fathoni Mahardika[8] pada STMIK Sumedang yang menggunakan NIST SP 800-30 Rev1 ini untuk menghasilkan penilaian risiko untuk membuat standar kebijakan bagi obyek masing-masing. Penelitian ini akan lebih berfokus kepada bagaimana menilai risiko pada sistem informasi Perpustakaan Daerah Purwokerto menggunakan NIST SP 800-30 dan memberikan rekomendasi dari hasil penilaian risiko tersebut. Dari hasil penelitian ini Perpustakaan Daerah Purwokerto dapat mengetahui risiko apa saja dan mengetahui rekomendasi apa yang dapat digunakan untuk mengatasi risiko tersebut.

\section{METODOLOGI PENELITAIN}

Tujuan penelitian ini adalah untuk melakukan penilaian risiko terhadap sistem informasi perpustakaan pada Perpustakaan Daerah Purwokerto. Pendekatan penelitian yang digunakan dalam penelitian ini adalah pendekatan model Kualitatif Memfasilitasi Kuantitatif. Dimana pada penelitian ini dilakukan wawancara dan observasi terlebih dahulu. Data kemudian dianalisis untuk menghasilkan praduga atas kejadian yang ada [9]. Pelaksanaan penelitian ini menggunakan metode NIST SP 800-30 Rev1. Langkah-langkah yang dilakukan untuk melakukan penelitian ini diperlihatkan pada gambar 1 . 


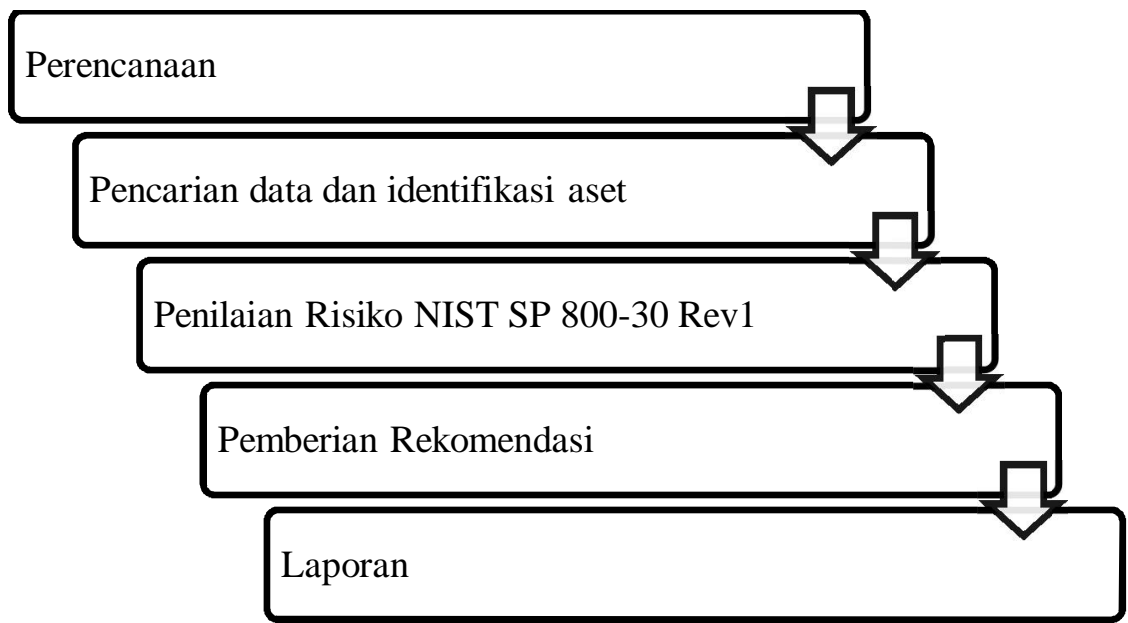

Gambar 1. Alur Penelitian

Tahapan penelitian yang dilakukan adalah pertama melakukan perencanaan dan persiapan untuk keperluan penelitian. Tahap berikutnya adalah melakukan pencarian data dan identifikasi aset dengan cara melakukan wawancara dan observasi keadaan Perpustakaan Daerah Purwokerto saat ini. Pada kegiatan wawancara dilakukan dengan tanya jawab kepada staff bidang IT. Jawaban dari narasumber akan dianalisis dan dilihat peranan control-nya serta potensi bahaya yang dapat ditimbulkan di dalam sistem. Untuk kegiatan observasi dilakukan dengan melihat keadaan lokasi penempatan teknologi dan sistem informasi di Perpustakaan Daerah Purwokerto.

Selanjutnya adalah melakukan penilaian risiko sistem informasi berdasarkan hasil data yang telah didapatkan melingkupi kegiatan [10]:

1. Meneliti sumber dan peristiwa ancaman utama pada obyek,

Kegiatan yang dilakukan pada tahap ini adalah mencari ancaman yang ada pada obyek dari berbagai sudut pandang baik itu sudut pandang teknologi maupun secara bisnis.

2. Mencari kelemahan pada obyek,

Mencoba mencari kelemahan pada obyek. Kelemahan yang dicari bukan hanya dari kelemahan sistemnya saja, tetapi juga dari aturan atau perilaku yang dapat menyebabkan ancaman terjadi.

3. Mencari kontol yang telah dilakukan,

Mencari kontrol yang telah dilakukan sebelumnya. Kontrol dapat berupa aturan atau peraturan yang jelas tertulis. Dan jika tidak ada dapat berupa kebiasaan obyek dalam menangani masalah.

4. Memperkirakan tingkat kemungkinan terjadinya ancaman,

Melakukan penilaian terhadap tingkat keseringan dari ancaman yang didapatkan pada obyek.

5. Menilai dampak dari ancaman kepada obyek,

Melakukan penilaian atas dampak buruk ancaman pada obyek.

6. Terakhir menilai tingkat risiko pada obyek.

Yaitu menilai tingkat risiko yang dihasilkan suatu ancaman terhadap obyek.

Langkah selanjutnya akan diberikan rekomendasi atas hasil penilaian risiko yang telah dilakukan disesuaikan dengan tingkat risiko yang telah dinilai. Dan langkah terakhir adalah laporan hasil keseluruhan. 


\section{HASIL DAN PEMBAHASAN}

Proses penilaian risiko yang dilakukan pada Perpustakaan Daerah Purwokerto adalah sebagai berikut:

\subsection{Identifikasi Aset}

Pada penelitian ini aset yang diteliti meliputi seluruh aset teknologi yang terdapat pada Perpustakaan Daerah Purwokerto. Dari hasil wawancara dan observasi didapati beberapa aset teknologi meliputi: perangkat keras komputer berupa personal komputer dan leptop yang digunakan oleh karyawan Perpustakaan Daerah Purwokerto. Selain itu terdapat personal komputer yang dapat digunakan oleh pengunjung.

Selanjutnya terdapat perangkat lunak yang berupa sistem informasi perpustakaan, sistem informasi aset, sistem informasi pelaporan keuangan, yang hanya dapat diakses oleh karyawan, dan tool pendukung lain (microsoft office dan browser) pada perangkat komputer yung dapat diakses oleh penggunjung perpustakaan daerah. Pada Perpustakaan Daerah Purwokerto juga telah terdapat jaringan internet dan jaringan lokal yang menghubungkan antara perangkat keras diseluruh gedung Perpustakaan Daerah Purwokerto.

\subsection{Identifikasi Ancaman}

Ancaman disebabkan atas beberapa sumber antara lain manusia, lingkungan, dan alam [5]. Pada penelitian ini dilakukan penilaian ancaman berdasarkan ketiga sumber ancaman tersebut. Berdasarkan hasil wawancara dan observasi yang dilakukan didapatkan ancaman pada perpustakaan daerah purwokerto terlihat pada tabel 1.

Tabel 1. Ancaman

\begin{tabular}{c|l} 
Kode & \multicolumn{1}{c}{ Ancaman } \\
\hline A1 & Pengoprasian yang salah \\
\hline A2 & Tindakan hacking \\
\hline A3 & Penyebaran virus \\
\hline A4 & Kehilangan data penting \\
\hline A5 & Perusakan peralatan \\
\hline A6 & Pencurian peralatan \\
\hline A7 & Gangguan jaringan listrik \\
\hline A8 & Gedung bocor \\
\hline A9 & Gangguan jaringan internet \\
\hline A10 & Kebakaran \\
\hline A11 & Gempa bumi \\
\hline A12 & Gunung Meletus \\
\hline A13 & Petir \\
\hline
\end{tabular}

\subsection{Identifikasi Kelemahan}

Pada kegiatan ini dilakukan pencarian kelemahan berdasarkan ancaman yang ada. Kelemahan yang ditemukan pada Perpustakaan Daerah Purwokerto diperlihatkan pada tabel 2. 


\begin{tabular}{c|l}
\multicolumn{1}{c}{ Kode } & \multicolumn{1}{|c}{ Kelemahan } \\
\hline $\mathbf{A 1}$ & $\begin{array}{l}\text { Pengguna sembarangan dan kadang tidak sesuai prosedur dalam } \\
\text { menggunakan sistem. }\end{array}$ \\
\hline $\mathbf{A 2}$ & Tidak ada pengawasan terhadap sistem informasi yang ada. \\
\hline $\mathbf{A 3}$ & $\begin{array}{l}\text { Pengguna dapat mengakses port USB pada Komputer yang } \\
\text { diletakkan untuk pengunjung. }\end{array}$ \\
\hline $\mathbf{A 4}$ & $\begin{array}{l}\text { Tidak adanya validasi bertingkat saat melakukan tindakan } \\
\text { penghapusan data atau perbaikan data. }\end{array}$ \\
\hline A5 & $\begin{array}{l}\text { Tidak ada pengamanan lebih pada peralatan, terutama pada peralatan } \\
\text { yang digunakan oleh umum. }\end{array}$ \\
\hline A6 & $\begin{array}{l}\text { Tidak ada pengamanan lebih pada peralatan, terutama pada peralatan } \\
\text { yang digunakan oleh umum. }\end{array}$ \\
\hline A7 & Tidak disediakan UPS untuk seluruh Peralatan computer. \\
\hline A8 & Terdapat kebocoran air terutama dari sekitar jendela. \\
\hline A9 & $\begin{array}{l}\text { Hanya terhubung pada 1 ISP saja sehingga sangat tergantung pada } \\
\text { ISP tersebut. }\end{array}$ \\
\hline A10 & $\begin{array}{l}\text { Kurangnya peralatan pemadam api, dan masih ditemukan orang yang } \\
\text { merokok disembarang tempat. }\end{array}$ \\
\hline A11 & $\begin{array}{l}\text { Kurangnya rambu petunjuk arah saat terjadi bencana, dan tidak ada } \\
\text { pembagian tangung jawab atas teknologi saat terjadi bencana. }\end{array}$ \\
\hline A12 & $\begin{array}{l}\text { Kurangnya rambu petunjuk arah saat terjadi bencana, dan tidak ada } \\
\text { pembagian tangung jawab atas teknologi saat terjadi bencana. }\end{array}$ \\
\hline A13 & Belum terdapat penangkal petir. \\
\hline
\end{tabular}

\subsection{Analisis Kontrol}

Pada tahap ini dicari kontrol apa saja yang ada pada obyek [10]. Pada Perpustakaan Daerah Purwokerto tidak memiliki aturan tertulis yang digunakan sebagai acuan dalam menentukan kontrol apa saja yang telah dilakukan. Dari hasil wawancara hanya didapati sebuah fakta bahwa jika terjadi hal permasalahan, maka akan diselesaikan mandiri oleh personil yang ada. Dan jika tidak ada lagi personil dilingkungan Perpustakaan Daerah Purwokerto yang dapat menyelesaikan permasalahan itu, maka akan dilimpahkan kepada pihak luar atau memanggil personil dari Dinas Komunikasi dan Informasi Kabupaten Banyumas.

\subsection{Tingkat kemungkinan ancaman}

Selanjutnya dinilai seberapa kemungkinan setiap ancaman yang telah diperoleh dapat terjadi dan menimpa Perpustakaan Daerah Purwokerto. Tingkat kemungkian ancaman ini dapat dilihat pada tabel 3. Tingkat kemungkinan ancaman dibagi menjadi 5 katagori [3]. Kemungkian VeryHigh, ancaman hampir pasti akan terjadi; atau terjadi lebih dari 100 kali setahun. Kemungkian High, ancaman sangat mungkin terjadi; atau terjadi antara 10-100 kali setahun. Kemungkian Moderate, ancaman kemungkinan besar akan terjadi; atau terjadi antara 1-10 kali setahun. Kemungkian Low, ancaman tidak mungkin terjadi; atau terjadi kurang dari sekali setahun, tetapi lebih dari sekali setiap 10 tahun. Dan Kemungkian VeryLow, ancaman sangat tidak mungkin terjadi; atau terjadi kurang dari sekali setiap 10 tahun. 
Tabel 3. Tingkat kemungkinan Ancaman.

\begin{tabular}{c|l} 
Kode & \multicolumn{1}{c}{$\begin{array}{c}\text { Kemungkinan } \\
\text { ancaman terjadi }\end{array}$} \\
\hline A1 & Moderate \\
\hline $\mathbf{A 2}$ & Low \\
\hline $\mathbf{A 3}$ & Moderate \\
\hline $\mathbf{A 4}$ & Moderate \\
\hline $\mathbf{A 5}$ & Low \\
\hline $\mathbf{A 6}$ & Low \\
\hline $\mathbf{A 7}$ & High \\
\hline $\mathbf{A 8}$ & Moderate \\
\hline $\mathbf{A 9}$ & High \\
\hline $\mathbf{A 1 0}$ & Very Low ${ }^{*}$ \\
\hline $\mathbf{A 1 1}$ & Low \\
\hline $\mathbf{A 1 2}$ & Very Low ${ }^{*}$ \\
\hline $\mathbf{A 1 3}$ & Low \\
\hline
\end{tabular}

Berdasarkan hasil analisis dari data yang didapat sebaran kemungkinan kejadian ancaman yang ada pada Perpustakaan Daerah Purwokerto dapat dilihat pada gambar 2.

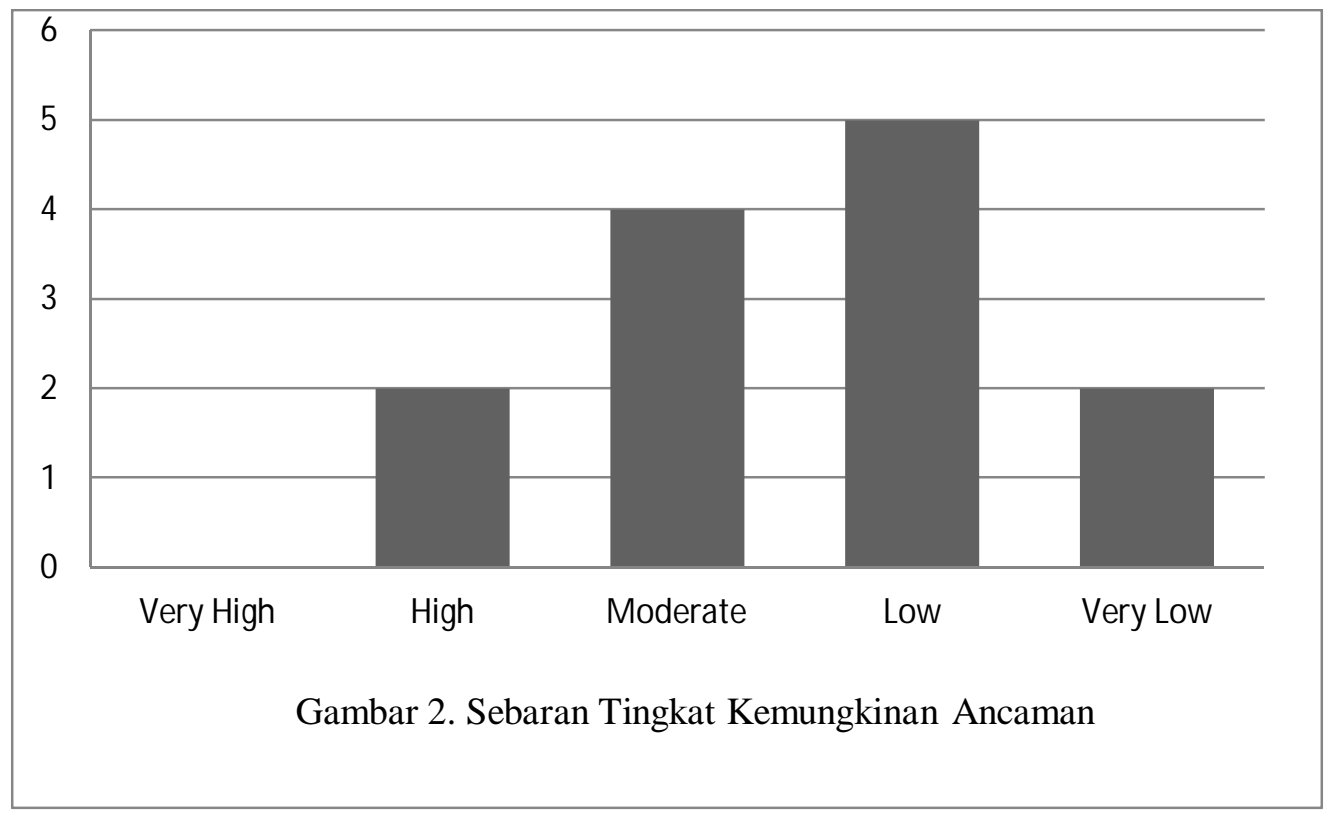

3.6 Penilaian Dampak

Penilaian dampak yang dilakukan berdasarkan atas beberapa aspek dan digolongkan menjadi beberapa kelas [3], yaitu kelas dampak Very High, peristiwa ancaman dapat diharapkan memiliki beberapa efek merugikan yang parah atau bencana pada operasi organisasi, aset organisasi, individu, organisasi lain, atau bangsa. Kelas dampak High, peristiwa ancaman dapat diharapkan memiliki efek buruk yang parah atau bencana pada operasi organisasi, aset organisasi, individu, organisasi lain, serta kelas dampak Moderate, peristiwa ancaman memiliki efek merugikan yang serius.

Berikutnya ada kelas dampak Low, peristiwa ancaman mengakibatkan kerugian kecil. Dan kelas dampak VeryLow, peristiwa ancaman dapat diharapkan memiliki efek merugikan

Ranggi, et.,al (Manajemen Risiko Sistem Informasi pada Perpustakaan Daerah Purwokerto) 
yang dapat diabaikan. Penilaian dampak ancaman pada Perpustakaan Daerah Purwokerto diperlihatkan pada tabel 4 .

Tabel 4. Dampak Ancaman.

\begin{tabular}{c|l} 
Kode & \multicolumn{1}{|c}{$\begin{array}{c}\text { Menghasilkan Dampak } \\
\text { Buruk }\end{array}$} \\
\hline $\mathbf{A 1}$ & Moderate \\
\hline $\mathbf{A 2}$ & High \\
\hline $\mathbf{A 3}$ & High \\
\hline $\mathbf{A 4}$ & High \\
\hline $\mathbf{A 5}$ & Very High \\
\hline $\mathbf{A 6}$ & High \\
\hline $\mathbf{A 7}$ & High \\
\hline $\mathbf{A 8}$ & Moderate \\
\hline $\mathbf{A 9}$ & Moderate \\
\hline $\mathbf{A 1 0}$ & Very High \\
\hline $\mathbf{A 1 1}$ & Very High \\
\hline $\mathbf{A 1 2}$ & High \\
\hline $\mathbf{A 1 3}$ & High \\
\hline
\end{tabular}

Berdasarkan hasil analisis dampak pada Perpustakaan Daerah Purwokerto didapatkan sebaran dampak negatif seperti yang dapat dilihat pada gambar 3.

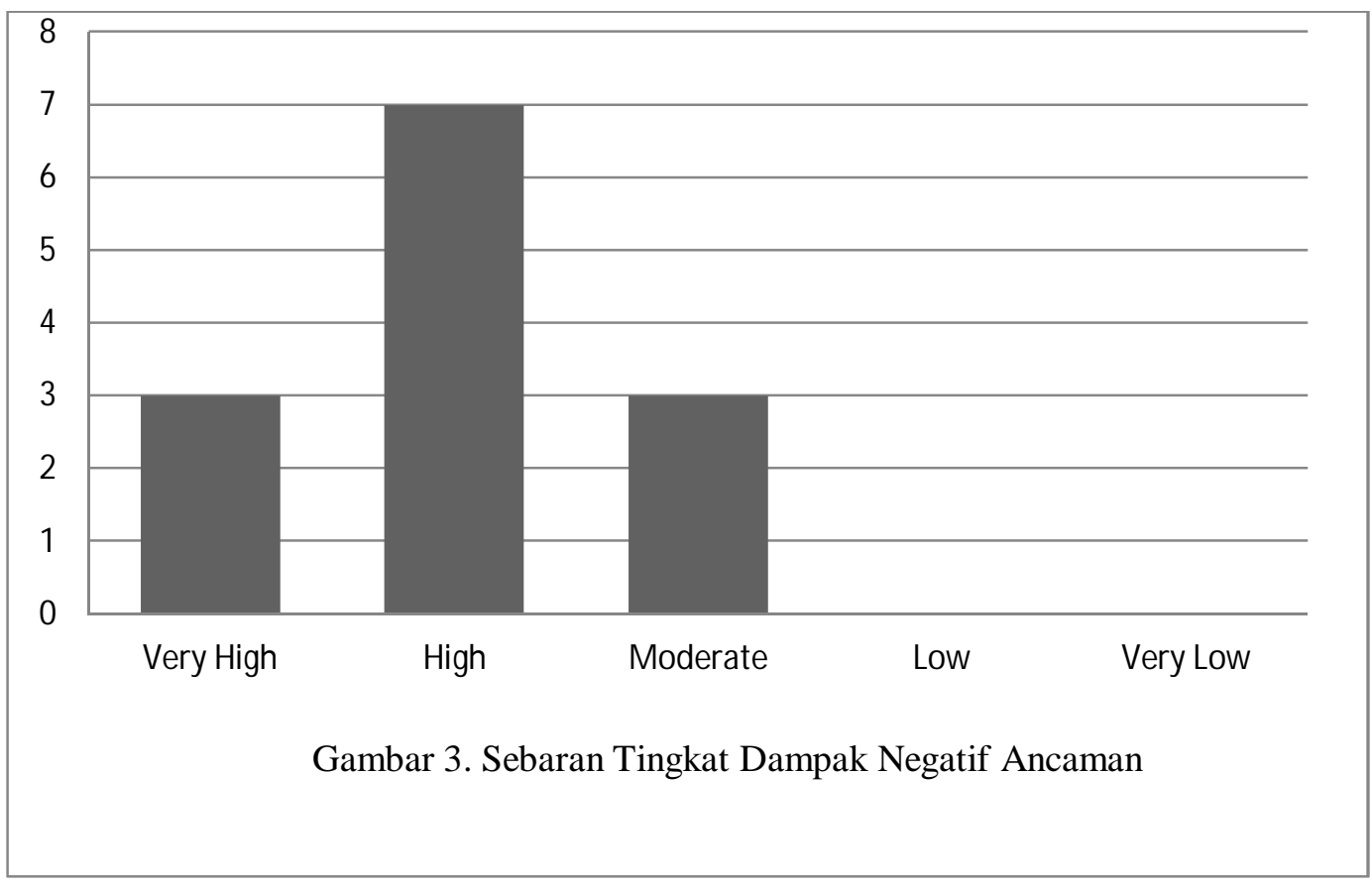

3.7 Penilaian Risiko

Dalam penilaian risiko, dapat dipergunakan rumus penilaian [11] sebagai berikut.

$$
\text { Risiko }=\text { Dampak } \times \text { Kemungkinan }(1)
$$


Dengan skor resiko Low adalah kurang dari 10 point. Nilai risko Moderate adalah berkisar antara 11 sampai 50 point. Dan untuk risiko High adalah berkisar antara 51-100. Untuk dampak memiliki skor 100 untuk High, 50 untuk Moderate, dan 10 untuk Low. Kemungkinan diberikan dalam nilai probabilitas 1,0 untuk kemungkinan High, 0,5 untuk kemungkinan Moderate, dan 0,1 untuk nilai kemungkinan Low[2]. Dari hasil penilaian atas dampak dan kemungkinan yang ada pada Perpustakaan Daerah Purwokerto didapatkan hasil rumusan risiko sebagai berikut diperlihatkan pada tabel 5 .

Tabel 5. Penilaian Risiko

\begin{tabular}{|c|c|c|l|l} 
Kode & $\begin{array}{c}\text { Kemungkinan } \\
\text { ancaman } \\
\text { terjadi }\end{array}$ & $\begin{array}{c}\text { Menghasilkan } \\
\text { Dampak } \\
\text { Buruk }\end{array}$ & Skor (1) & \multicolumn{1}{|c}{$\begin{array}{c}\text { Tingkat } \\
\text { Risiko }\end{array}$} \\
\hline $\mathbf{A 1}$ & 0.5 & 50 & 25 & Moderate \\
\hline $\mathbf{A 2}$ & 0.1 & 100 & 10 & Low \\
\hline $\mathbf{A 3}$ & 0.5 & 100 & 50 & Moderate \\
\hline $\mathbf{A 4}$ & 0.5 & 100 & 50 & Moderate \\
\hline $\mathbf{A 5}$ & 0.1 & $100^{*}$ & 10 & Low \\
\hline $\mathbf{A 6}$ & 0.1 & 100 & 10 & Low \\
\hline $\mathbf{A 7}$ & 1.0 & 100 & 100 & High \\
\hline $\mathbf{A 8}$ & 0.5 & 50 & 25 & Moderate \\
\hline $\mathbf{A 9}$ & 1.0 & 50 & 50 & Moderate \\
\hline $\mathbf{A 1 0}$ & $0.1^{*}$ & $100^{*}$ & 10 & Low $*$ \\
\hline $\mathbf{A 1 1}$ & 0.1 & $100^{*}$ & 10 & Low \\
\hline $\mathbf{A 1 2}$ & $0.1^{*}$ & 100 & 10 & Low \\
\hline $\mathbf{A 1 3}$ & 0.1 & 100 & 10 & Moderate \\
\hline & & & & \\
\hline
\end{tabular}

Berdasarkan hasil perhitungan risiko pada Perpustakaan Daerah Purwokerto didapatkan sebaran risiko seperti yang dapat dilihat pada gambar 4 . 


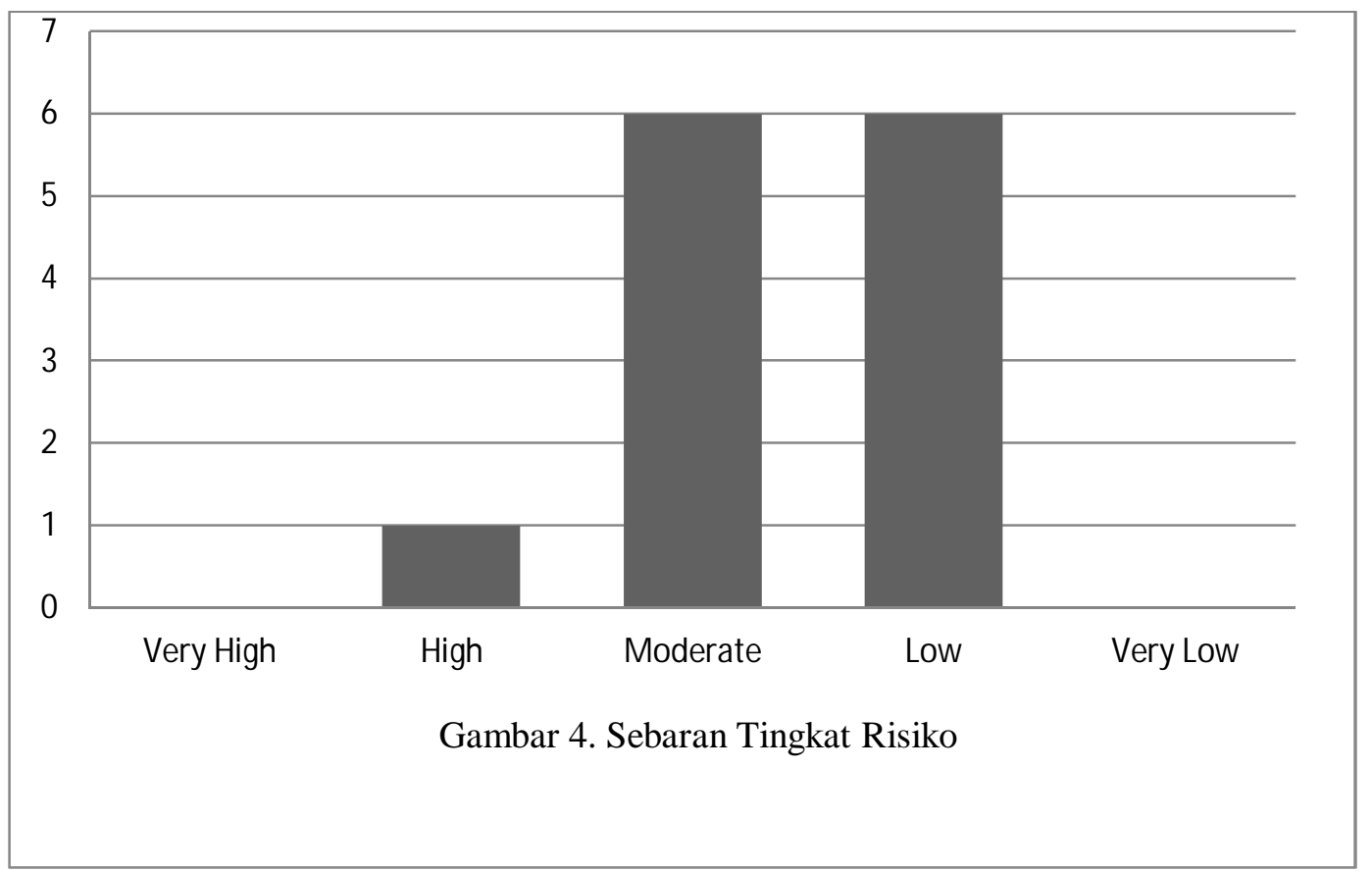

\subsection{Rekomendasi}

Pemberian rekomendasi ini dimaksudkan agar perpustakaan daerah siap dalam menghadapi risiko yang ada [2]. Pemberian rekomendasi ini disesuaikan dengan tingkat risiko yang sebelumnya telah dihitung. Tabel 6 memperlihatkan secara lengkap rekomendasi yang diberikan.

Tabel 6. Rekomendasi

\begin{tabular}{c|c|l} 
Kode & \multicolumn{1}{c}{$\begin{array}{l}\text { Tingkat } \\
\text { Risiko }\end{array}$} & \multicolumn{1}{c}{ Rekomendasi } \\
\hline $\mathbf{A 1}$ & Moderate & $\begin{array}{l}\text { Perlunya dibuat aturan tertulis sehingga semua piihak dapat } \\
\text { menggunakan seluruh teknologi yang ada dengan benar. }\end{array}$ \\
\hline $\mathbf{A 3}$ & Moderate & $\begin{array}{l}\text { Perlunya pembatasan akses terhadap device dari luar dengan } \\
\text { mematikan akses USB port pada komputer yang digunakan oleh } \\
\text { orang umum, dan mengaktifkan antivirus dan protokol firewall } \\
\text { pada perangkat karyawan. }\end{array}$ \\
\hline $\mathbf{A 4}$ & Moderate & $\begin{array}{l}\text { Adanya personil yang diberi tanggung jawab verifikasi atas } \\
\text { perubahan dan penghapusan data. }\end{array}$ \\
\hline $\mathbf{A 5}$ & Low* & $\begin{array}{l}\text { Adanya petugas keamanan yang dapat menjaga barang yang ada } \\
\text { dari perusakan. }\end{array}$ \\
\hline $\mathbf{A 7}$ & High & $\begin{array}{l}\text { Disediakan genset atau UPS untuk menjaga keberlangsungan } \\
\text { teknologi informasi yang ada sehingga tidak langsung off saat } \\
\text { listrik tidak stabil. }\end{array}$ \\
\hline A9 & Moderate & $\begin{array}{l}\text { Perbaikan ditempat yang didapati bocor atau terdapat rembesan } \\
\text { air. }\end{array}$ \\
\hline A11 & Moderate & $\begin{array}{l}\text { Menggunakan lebih dari 1 ISP. } \\
\text { Libuat rambu dan pengumuman tindakan apa yang perlu diambil } \\
\text { saat bencana terjadi. }\end{array}$ \\
\hline
\end{tabular}

Ranggi, et.,al (Manajemen Risiko Sistem Informasi pada Perpustakaan Daerah Purwokerto) 


\begin{tabular}{l|l|l}
\hline A13 & Sedang & $\begin{array}{l}\text { Dipasangkan alat penangkal petir sehingga jaringan listrik aman } \\
\text { dari sambaran petir. }\end{array}$ \\
\hline
\end{tabular}

\subsection{Pembahasan}

Dari analisis yang telah dilakukan terdapat 2 ancaman dengan tingkat kemungkinan besar terjadi yaitu ancaman A7 gangguan jaringan listrik dan A9 gangguan jaringan internet. Kedua ancaman ini sering sekali terjadi pada Perpustakaan Daerah Purwokerto dan saat terjadi ancaman ini bisa dipastikan kegiatan operasional perpustakaan berhenti. Dilihat dari dampaknya terhadap Perpustakaan Daerah Purwokerto terdapat beberapa ancaman yang memiliki tingkat dampak sangat tinggi jika sampai ancaman tersebut terjadi. Ancaman yang berdampak sangat besar A5 perusakan peralatan, A10 kebakaran, dan A11 gempa bumi.

Kontrol pengendalian pada Perpustakaan Daerah Purwokerto adalah bersifat mandiri. Artinya setiap karyawan hanya mengetahui bahwa apa yang dia miliki saja yang perlu diamankan. Sehingga menyebabkan ancaman diatas dapat sangat berpengaruh jika sampai ancaman tersebut terjadi. Selain itu dengan keadaan kontrol pengendalian seperti ini risiko kecil sekalipun sangat penting untuk diperhatikan.

Dari tahap penilaian risiko diperoleh hasil berupa 6 ancaman dengan tingkat kecil, 6 ancaman bertingkat sedang, dan 1 ancaman dengan tingkat tinggi. Namun demikian peneliti menemukan adanya ancaman bertingkat risiko rendah namun memiliki dampak yang sangat besar sehinga perlu menjadi catatan untuk pihak Perpustakaan Daerah Purwokerto dalam mengamankan ancaman tersebut yaitu ancaman A5 perusakan peralatan dan ancaman A11 gempa bumi.

Perlunya perbaikan dengan membuat sebuah aturan tertulis yang dapat memberikan pengetahuan saat terjadi ancaman pengamanan fisik, dan ancaman pengaksesan device yang berasal dari luar organisasi. Serta perlu dibuatkan aturan saat terjadi bencana alam atau lingkungan seperti gempa bumi, kebakaran dan gunung berapi. Selain itu adanya petugas keamanan dan personil perpustakaan yang bertugas memberikan validasi saat dilakukan kegiatan penghapusan atau perubahan data pada sistem yang ada menjadikan keamanan di Perpustakaan Daerah Purwokerto dari segi fisik dan logik lebih aman.

\section{KESIMPULAN}

Terdapat beberapa ancaman yang dapat memberikan risiko terhadap keberadaan sistem informasi di Perpustakaan Daerah Purwokerto. Ancaman dengan kode A1 pengoperasian yang salah, A3 penyebaran virus, A4 kehilangan data penting, A8 gedung bocor, A9 gangguan jaringan internet, dan A13 petir merupakan ancaman dengan tingkat risko Moderate yang harus di perhatikan. Selanjutnya ada ancaman dengan kode A5 perusakan peralatan dan A11 gempa bumi, yang merupakan ancaman dengan level risiko Low namun memiliki dampak yang berada pada tingkat High bahkan Very High sehingga masih perlu diperhitungkan untuk dilakukan peningkatan kesadaran dan keamanan. Dan ancaman dengan kode A7 gangguan jaringan listrik, merupakan ancaman dengan level risiko High yang dapat merugikan bagi Perpustakaan Daerah Purwokerto jika tidak segera ditanggulangi.

Beberapa hal yang perlu dilakukan oleh Perpustakaan Daerah Purwokerto antara lain membuat aturan tertulis dalam menangani bencana alam, pengamanan fisik dan logik pada peralatan yang ada. Serta menempatkan pihak keamanan dan personil yang bertugas melakukan validasi saat dilakukan kegiatan penghapusan atau perubahan data pada sistem. 


\section{SARAN}

Pada penelitian ini didapati beberapa bagian dari infrastruktur teknologi informasi yang ada pada Perpustakaan Daerah Purwokerto masih belum sempurna dikarenakan adanya aspekaspek teknologi informasi yang belum ada atau kurang. Untuk penelitian selanjutnya dapat dilakukan penelitian mengenai infratruktur teknologi informasi sehingga harapannya dapat melengkapi dan menyempurnakan infrastruktur teknologi informasi yang ada pada saat ini. Selain itu juga belum adanya manajemen pengelolalan sistem informasi yang baik pada Perpustakaan Daerah Purwokerto menyebabkan pengelolaan sistem informasi yang tidak tertata dengan baik.

\section{UCAPAN TERIMAKASIH}

Termakasih kepada Universitas AMIKOM Purwokerto yang terlah mendukung pelaksanaan dari kegiatan Penelitian ini. Dukungan Universitas AMIKOM Purwokerto dalam bentuk Pendanaan Penelitian Dosen Muda Amikom menjadikan kegiatan ini berjalan dengan baik dan lancer. Serta tidak lupa kami mengucapkan terimakasih kepada pihak Perpustakaan Daerah Purwokertoyang telah mengijinkan dan membantu saya dan tim melengkapi data penelitian yang kami lakukan.

\section{DAFTAR PUSTAKA}

[1] K. Harsanto and D. Hidayat, 2018, Sistem Informasi Manajemen Risiko dengan Menggunakan Framework National Institute of Standards and Technology pada Lembaga Pendidikan, J. Ipsikom, Vol. 6, No. 1.

[2] D. I. Izatri, N. I. Rohmah, and R. S. Dewi. 2020, Identifikasi Risiko pada Perpustakaan Daerah Gresik Dengan NIST SP 800-30, JURIKOM (Jurnal Ris. Komputer), Vol. 7, No. 1, p. 50 ,

[3] NIST. 2012, Guide for Conducting Risk Assessments, Gaithersburg, MD,

[4] H. B. Santoso and L. Ernawati. 2017, Manajemen Risiko pada Pusat Data Perguruan Tinggi Dengan Kerangka Kerja NIST 800 - 30 ( Studi Kasus: Universitas Kristen Duta Wacana), J. Inform. dan Sist. Inf. Univ. Ciputra, vol. 03, no. 02, pp. 8-17.

[5] B. A. Nugraha, A. R. Perdanakusuma, and A. Rachmadi. 2020., Analisa Manajemen Risiko pada Sistem Informasi Tata Naskah Dinas Elektronik Dengan Kerangka Kerja NIST 800-30 pada Dinas Komunikasi dan Informatika Provinsi Jawa Timur, J. Pengemb. Teknol. Inf. dan Ilmu Komput., Vol. 4, No. 1, pp. 223-231.

[6] R. R. Putra. 2019, Analisis Manajemen Risiko TI pada Keamanan Data E - Learning dan Aset IT Menggunakan NIST SP 800 - 30 Revisi 1, JATISI (Jurnal Tek. Inform. dan Sist. Informasi), Vol. 6, No. 1, pp. 96-105.

[7] R. A. Ashari. 2018., Rencana Penerapan Cyber-Risk Management Menggunakan NIST CSF dan COBIT 5, J. Sist. Inf., Vol. 14, No. 2, pp. 83-89.

Ranggi, et.,al (Manajemen Risiko Sistem Informasi pada Perpustakaan Daerah Purwokerto) 
[8] F. Mahardika. 2017, Manajemen Risiko Keamanan Informasi Menggunakan Framework NIST SP 800-30 Revisi 1 (Studi Kasus: STMIK Sumedang), JIPT (Jurnal Pengemb. IT), Vol. 02, No. 02, pp. 1-8.

[9] M. Mulyadi. 2013, Penelitian Kuantitatif dan Kualitatif Serta Pemikiran Dasar Menggabungkannya, J. Stud. Komun. dan Media, Vol. 15, No. 1, p. 128.

[10] W. Syafitri. 2016, Penilaian Risiko Keamanan Informasi Menggunakan Metode NIST 800-30 (Studi Kasus: Sistem Informasi Akademik Universitas XYZ), J. CoreIT J. Has. Penelit. Ilmu Komput. dan Teknol. Inf., Vol. 2, No. 2, p. 8.

[11] F. K. Muttaqi. 2019, Manajemen Risiko Sistem Informasi Rumah Sakit Menggunakan Framework NIST SP 800-30 (Studi Kasus: RSIA Eria Bunda Pekanbaru), Pros. Semin. Nas. Comput. Technol. its Apl., Vol. 1, pp. 86-96. 